

\section{Singapore's Foreign Policy: A Book Review}

Hardi Alunaza SD

Universitas Tanjungpura

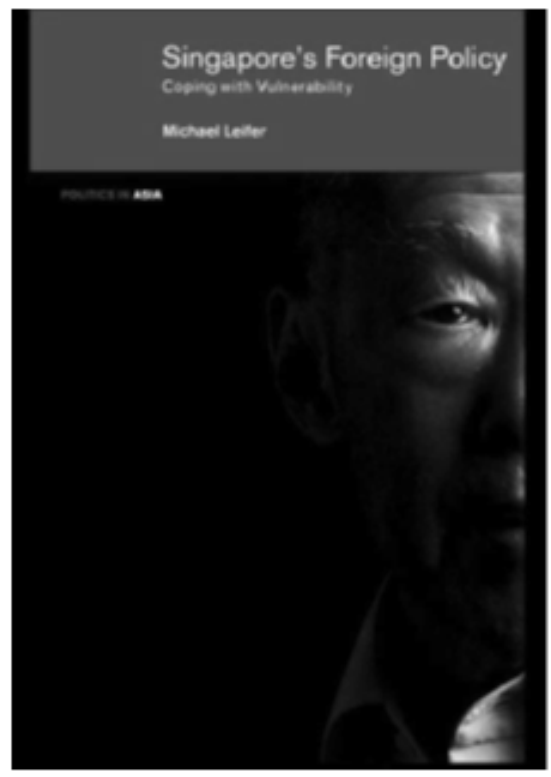

Title

Policy Coping With
Vulnerability

Author

Publisher

ISBN

Year

Number of page : $177+$ xiv pages

This book contains five chapter with a specific explain and contribution in every chapter. The first chapter is about Singapore's foreign policy and explains about exceptional state. The second chapter is talking about the battle of sovereignty. The third is about transcending regional locale. The fourth explaining about Singapore and the power, and the last is about driving and suffering the region. The Island Republic of Singapore is the smallest state within South-East Asia and, indeed, within a wider East Asia. It also lacks natural resources, except for the human variety in limited numbers, and a harbor in an ideal location for servicing regional trade. In 1999, for the third year running, the Swiss based world economic forum ranked Singapore first among over fifty leading economies in its annual global competitiveness report. In its material accomplishments and attendant external recognition, Singapore is exceptional not only within its regional locale, but also globally among so called small states. The point has been well made that economic success is the main reason for Singapore's high status and disproportionate influence in international affairs. 
A size of some 648 square kilometers, a citizen and permanent resident population combined of around 3.2 million together with a confined geographic situation at the southern tip of peninsular Malaysia provide, on their own, misleading indicators of the remarkable achievements and international standing which have been attained in the years since an unanticipated independence in August 1965. For that reason, in addressing its foreign policy, Singapore is not to be located readily within broad generalizations about the category of small and micro states to be found in an ill defined academic literature Singapore shares some common features with some states in that loose category; notably, an innate vulnerability arising from geopolitical circumstances which was registered at independence as the leitmotif of foreign policy.

That underlying vulnerability has persisted, but its economic and environmental achievements, and also its regional diplomatic role, place it in a virtual category of its own so that Singapore is best represented as sui generis, irrespective of its size. Correspondingly, given its notable accomplishments, it is also not easy to locate Singapore comfortably within the overlapping category of weak states which has succeeded small states as a more pertinent label in academic literature.

In assessing the exceptional nature of Singapore's international position, Hong Kong might be identified as a regional comparator of a kind, but only as a major centre of economic activity which has enjoyed a unique linkage with the Chinese mainland. For long a colony without conventional international status, and since July 1997 a special administrative region of China, Hong Kong has been an international actor in a limited sense only through its qualified membership of some economic organizations. An additional comparison between Singapore and Hong Kong is valid up to a point in one particular respect, in that the overwhelming majority of the island state's population is ethnic Chinese with links to a dynamic economic network of overseas Chinese and to China itself.

A comparison of a kind might be attempted also between Singapore and some of the small oil rich Gulf sultanates, such as Bahrain and Kuwait, with which the island state shares the experience of both wealth and vulnerability but not that of natural resources. Indeed, in the case of Kuwait, a sense of shared vulnerability was openly articulated with Iraq's invasion in August 1990. Neither Bahrain nor Kuwait have matched Singapore, however, in scale and range of economic achievements and in active diplomatic role; nor have they registered the same sophistication and proficiency in their educational and defence establishments.

In the context of an abiding vulnerability, Singapore's exceptional standing and influence do not arise from its military might, even though its defence resources, designed primarily with deterrence in mind, are consid- 
erable for a state of its limited physical scale and population. Nonetheless, the resources allocated for defence serve as a clear indication of the government's determination to compensate for natural shortcomings employing the societal concept of total defence drawn from Swedish experience. In 1999, Singapore's defence budget was three times that of neighbouring Indonesia which has a population of some 210 million and an extensive archipelago to police. The same disparity applied in the case of Malaysia, its other close neighbour, which has a population of 22 million.

Singapore's defence establishment draws on limited human resources. It is modelled on Israeli lines employing only a small cadre of 50,000 professional soldiers complemented by 250,000 national servicemen. National service of two to two and a half years is compulsory for all males at the age of 18, who, after its completion, are obliged to undergo regular reserve training and service, in principle, up to the age of 45 . Singapore's defence establishment operates within tight geopolitical confines, wedged between Malaysian and Indonesian sea and airspace, mitigated operationally by access to extensive training facilities in Australia, Brunei, New Zealand, the USA, Taiwan and Thailand and, most recently, in France and South Africa. A deterrent capability based on modern weapons and sophisticated training as well as a growing competence in manufacturing arms has to be set against a lack of combat experience and minimal involvement in United Nations peacekeeping operations.

The condition of Singapore at the beginning of the twenty first century stands in marked contrast to that which obtained on the morrow of independence in 1965. A new state without a hinterland has succeeded in making a hinterland of the global economy with conspicuous success. Moreover, the way in which the regionally contagious economic adversity was addressed at the end of the last century demonstrated an underlying resilience based on a system of governance respected for its efficiency and probity.

Singapore's government has not been addicted to multilateralism in foreign policy for its own sake. It has promoted its prime interests through bilateral arrangements in defence and economic cooperation. Nonetheless, ASEAN has been very much at the centre of its foreign policy practice, permitting a collective diplomacy which has served the interests of the Republic well. ASEAN demonstrated its utility over the Cambodian conflict, albeit in exceptional circumstances, and served as a vehicle for successful initiatives leading to the ARF and to ASEM, for example. Through ASEAN, Singapore sought to embed itself regionally as a political partner of governments that exhibited mixed feelings towards it. That facility for political solidarity has been weakened through the institutional failings of an enlarged Association and its lack of a common focus post Cambodia, without any substantive 
compensation for Singapore, so far, from the advent of the ASEAN Regional Forum. The ARF has not progressed beyond a minimal confidence building role, although it still serves Singapore's interests through providing an institutional locus for dialogue among the major Asia Pacific powers, especially the USA and China.

Set against the failings of ASEAN and the limitations of the ARF, Singapore's policy makers can take some comfort from the absence of acute conflicts within South-East Asia since the end of the Cold War. There is, of course, the exception of the potential inherent in that over the islands in the South China Sea, where it is not a claimant state. Moreover, as long as sources of energy in commercial quantities are not discovered beneath the sea-bed, the contention over the Spratly Islands, in particular, should not get out of hand. In addition, although within a wider East Asia, the issues of Taiwan and the Korean Peninsula continue to display a potential for armed confrontation, the strategic environment has remained relatively stable, in part, because of the degree of Sino American accommodation.

In Singapore, it is believed that China would not have had the temerity to seize Mischief Reef in the Spratly Islands had the USA not withdrawn previously from its military bases in the Philippines. Correspondingly, the display of resolve by the Clinton administration in March 1996 in deploying two carrier groups to the vicinity of Taiwan in response to China's attempt to influence the outcome of presidential elections through armed intimidation was quietly welcomed as a demonstration of the viability of a regional balance of power predicated on an American military presence. Singapore has contributed to that balance, or, more accurately, distribution of power by providing facilities for America's air force and navy. And, in the case of China, a policy of engagement has been advocated as the most practical way of giving the People's Republic a stake in regional stability. It is well understood in Singapore that the island state is primarily a spectator to the evolving pattern of power in the Asia Pacific, which is why the American military connection is highly valued.

The more local distribution of power has been served up to a point by the Five Power Defence Arrangements in collaboration with Malaysia, Britain, Australia and New Zealand. These arrangements have suffered from ups and downs in the relationship across the causeway, but have been sustained by the growing interest of Australia in playing a role, in the interest of regional stability. They are valued in Singapore because of the Australian connection in particular, and because of the additional indirect link to the USA with which Australia is in an alliance relationship.

They also provide a channel of communication between Singaporean and Malaysian defence counterparts. The five power defence Arrangements do not provide a security guarantee for Singapore. They are regarded as a 
vehicle for confidence building of a limited kind, and also as a barometer of the state of relations with Malaysia, with which Singapore has experienced the most turbulent exchanges. For example, Five Power joint exercises were called off in September 1998, when Malaysia withdrew at short notice citing economic difficulties, but were then resumed in April 1999. They are valued most of all, however, because they continue to draw in countries in addition to Malaysia with which Singapore has enjoyed long-standing good relationships.

With the devastating impact of regional economic adversity at the end of the twentieth century, Singapore's scope for initiative within collective diplomatic frameworks involving its regional partners has been considerably reduced, although Prime Minister Goh Chok Tong has promoted the idea of an Asia Latin American forum to match ASEM. In the case of ASEAN, expectations have been downgraded to await a possible restoration of regional economic vibrancy. In that context, Singapore's main initiative at the turn of the new millennium has been in the realm of foreign economic policy where government directed initiatives towards liberalization in banking and financial services have been intended to improve the international competitive economic edge of the Republic.

Beyond such minimal initiative, Singapore displays continuity in the influence on foreign policy of Senior Minister, Lee Yuan Yew. His political perspective, including the conviction that Singapore cannot take its independence for granted and that continual adaptation is required for survival, is part of the conventional wisdom of the successor generation of political leaders. As noted above, Lee Kuan Yew has combined a razor-sharp intellect and a remarkable experience with a disposition for speaking his mind on political matters which has not always helped in managing relations with Singapore's closest neighbours, Malaysia and Indonesia. Indeed, some of his obiter dicta have served to point up the persisting vulnerability of the Republic through the hostile reactions of those governments.

In one obvious sense, Singapore has no alternative but to stay in its little pond. That has been its geopolitical fate ever since August 1965 and is the source of its abiding vulnerability. It is also the source of an extraordinary political morbidity about addressing the viability of the island-state. In seeking to cope with an innate vulnerability, there are no illusions about the task involved, despite an innovative culture that has been responsible for an extraordinary achievement. Indeed, Singapore copes with vulnerability by trying to be extraordinary in the way in which its achievements are projected and perceived well beyond its little pond. In the process, nothing is taken for granted and nothing is guaranteed.

This review offer four main reason to challenge the conventional realist understanding of Singapore's foreign policy. First, it neglects the strong 
underpinnings of Singapore's economic and security policy in liberal market economics. In fact, the most famous books on Singapore's foreign policy have paid little attention to the economic underpinnings of its national security. And the speech of foreign minister S. Rajaratnam that demonstrates Singapore economic policy and its national security approach.

Second, realists vastly overstate the balance of power approach to regional order in Singapore's foreign policy at the expense of the multilateralist and regionalist approach. Singapore's close identification with the US security strategy in the region, based on the belief that the US is the indispensable regional balancer, is a fact. Singapore's policy makers, despite extoling the beneficial effects of the US military presence, are also acutely aware of the potential and actual costs of security dependence it engenders. Third argument against the conventional view is that it seriously understates the impact of ASEAN in realizing Singapore's vital foreign policy and security interests, including the preservation of its sovereignty and territorial integrity. Few accounts of Singapore's foreign policy have seriously wondered how, without the regionalist turn in Indonesia's foreign policy under Suharto, would Singapore have managed its security at a time of British withdrawal from the east of Suez, the US preoccupation in Vietnam and the Nixon Doctrine's stipulation regarding avoiding further direct military intervention in Asia, especially at a time when Singapore's own self defense forces were too miniscule to provide credible deterrence.

Fourth, the conventional view also understates the significance of Singapore's role in global multilateral forums and especially in the development of regionalism in Southeast Asia. Belying the standard realist pessimism about the relevance and effectiveness of international institutions, Singapore has produced some of the ablest multilateralists in its diplomatic corps, as evident in Tommy Koh's stewardship of the UN Law of the Sea Conference and the UN Conference on Environment and Development in Rio.

The contribution of this book is really represents a highly significant for international relations student whose studying and learning about foreign policy of each country. Then, this books also tell us how Singapore's foreign policy explained and gives a great attention for the others country like Indonesia. In my humble opinion, it is possible that Singapore's foreign policy maker might have occasionally engaged in such cheap talk about regional cooperation. Singapore's foreign policy practices an uncompromising approach to regional order in which national defence capabilities and balance of power considerations reign supreme obscures a more complex pictures in which regional interdependence and interaction have held a prominent place. Even when its instincts may be fiercely competitive and zero sum, cooperation is forced on the city-state by geographic realities and an evolving world order in which national interest is deeply enmeshed in regional existence and international interdependence. 